\title{
A GENTRFFICAÇ̃̃o DO BAIRRO DO RECIFE ENTRE OS ANOS 1980 E 2010
}

\section{THE GENTRIFICATION OF BAIRRO DO RECIFE BETWEEN 1980'S AND 2010'S}

\author{
Tarciso Binoti Simas ${ }^{1}$
}

Sônia Azevedo Le Cocq Oliveira²

Carlos Maviael Carvalho³

Recebido em: 11 de julho de 2020

Aprovado em: 10 de novembro de 2020

RESUMO: Devido às diversas propostas urbanísticas para o Bairro do Recife desde os anos 1980, o objetivo principal deste trabaIho é analisar suas principais transformações ao longo dessas últimas décadas. Trata-se de uma pesquisa exploratória sobre os diferentes projetos e seus impactos sobre seu território e sua população. As evidências de valorização imobiliária, êxodo de parte da população e entrada de novos consumidores permitem constatar o processo de gentrificação voltado ao entretenimento, turismo e ao parque empresarial do Porto Digital.

Palavras-chave: Gentrificação; Planejamento estratégico; Recife.
ABSTRACT: Due to many urbanistic proposals for Bairro do Recife since the 1980 s, the main objective of this work is to analyze its main transformations over the past decades. It is an exploratory research about different projects and their impacts on their territory and their population. Evidences of real estate valorization, the exodus of part of the population and the entry of new consumers allow us to see the gentrification process focused on entertainment, tourism and the Porto Digital business park.

Keywords: Gentrification; Strategic planning; Recife.

1 Arquiteto e Urbanista pela Universidade Federal do Rio de Janeiro - UFRJ (2009), Mestre em Engenharia de Transportes pelo Programa de Engenharia de Transportes - PET/COPPE/UFRJ (2013) e Doutor em Urbanismo pelo Programa de Pós-Graduação em Urbanismo - PROURB/UFRJ (2018), com intercâmbio (sanduíche) pela Universitat de Barcelona (2017). Atualmente, é Diretor-Adjunto do Instituto de Engenharia do Araguaia da Universidade Federal do Sul e Sudeste do Pará - IEA/UNIFESSPA (desde 2020), Coordenador e Professor Adjunto dos cursos de Arquitetura e Urbanismo - Santana do Araguaia (desde 2019) e de Engenharia Civil - Redenção (desde 2020). E-mail: tarcisobinoti@gmail.com.

2 Possui graduação em Arquitetura e Urbanismo pela Universidade Federal do Rio de Janeiro(1979), mestrado em Planejamento Urbano e Regional pela Universidade Federal do Rio de Janeiro(1988) e doutorado em Sociologia e Antropologia pela Universidade Federal do Rio de Janeiro(1999). Atualmente é Professor Adjunto da Universidade Federal do Rio de Janeiro. E-mail: sonialecocq@ gmail.com.

3 Possui Graduação em Engenharia de Materiais pela Universidade Federal da Paraíba, Mestrado em Engenharia de Materiais pela Universidade Federal da Paraíba, e também pós-graduação em Segurança do Trabalho. É doutor em Ciência e Engenharia de Materiais pela da Universidade Federal da Paraíba. Consultor nas áreas de cerâmicas, concretos, cimentos, argamassas. Atualmente é professor da universidade Federal do Sul e Sudeste do Pará (UNIFESSPA). E-mail: maviael.mcarvalho@gmail.com. 
Bairro do Recife é o berço de fundação da cidade do Recife, Pernambuco. Desde os anos 1980, esse território tornou-se alvo de propostas de planejamento urbano reconhecendo seu patrimônio edificado com diferentes paradigmas. Suas maiores transformações acontecem através de planos/ projetos que aderiram à moda do planejamento estratégico estadunidense colocando essa área deprimida de investimento no foco para realização de negócios imobiliários, turísticos e de entretenimento. Para maior compreensão desse processo como um todo, é necessário relacionar diferentes planos, projetos e seus impactos. Assim, o objetivo deste trabalho é analisar as principais transformações urbanas no Bairro do Recife e em sua população. Como referencial teórico, são contextualizados o modelo de planejamento estratégico de cidades estadunidenses dos anos 1970-80 e a ampliação dos processos de gentrificação como estratégia urbana neoliberal. Isso permite construir a proposta metodológica que conta com coleta de dados bibliográficos, documental, por observação no local e entrevistas.

\section{Referencial teórico}

Após a crise econômica da década de 1970, as cidades estadunidenses vivenciaram uma escassez na geração de renda e de empregos e em recursos federais na gestão liberal do presidente Ronald Reagen (1981-89). Algumas administrações aumentaram então seus esforços em estratégias de incentivos fiscais e urbanísticos e de marketing para aumento de competitividade na atração por investidores, em um modelo que ficou conhecido como planejamento estratégico. De acordo com Carlos Vainer (2013), esse modelo foi inspirado em conceitos e técnicas do planejamento empresarial da Harvard Business School e, segundo seus idealizadores ou seguidores, as cidades estariam então submetidas as mesmas condições e desafios das empresas. Nesses moldes, Lima Junior (2010) aponta que a administração pública, antes vista como burocrática, assume uma postura de gestão, estratégia, estrutura e promoção semelhante à administração de empresas (principalmente as globais) e passa a oferecer externalidades e a aumentar a publicidade para atrair a preferência de capitais em fluxo.

Com isso, nas décadas de 1970-80, algumas prefeituras enxergaram as zonas portuárias obsoletas e desvalorizadas como uma oportunidade de negócio de grande escala em Parceria Público-Privada (PPP) com a oferta de subsídios e incentivos. O poder municipal passou então a assumir os riscos de projetos de revitalização em "áreas estratégicas", deixando o planejamento geral da cidade em segundo plano. A gestão desses projetos ficou na responsabilidade de corporações semi-públicas, que reforçaram a busca incessante por reprodução do capital. O porto interno (inner harbor) de Baltimore é um dos projetos mais emblemáticos desse modelo de revitalização de waterfront que resultou em aquário, mercado convertido para uso turístico e de lazer, obras de arquitetos renomados com grande visibilidade, pedestrianização do espaço público, aumento do valor imobiliário e negócios de turismo.

Por um lado, sua população "ganhou" um legado de infraestruturas, eventos, equipamentos coletivos e qualidade em espaço público vendendo assim o "sucesso" na melhoria da qualidade de 
vida, que se restringia aos cidadãos com poder de compra. Por outro lado, a população de baixa renda passa a vivenciar processos de gentrificação. Esse conceito de gentrificação é um termo aportuguesado da palavra em inglês gentrification, derivação de gentry que pode ser traduzida como alta burguesia ou pequena nobreza. Foi construído por Ruth Glass em 1964 ao descrever no livro London: Aspects of Change um fenômeno de renovação de moradias no bairro de Londres de Islington com o êxodo dos habitantes de classe trabalhadora (OMM, 2015).

Segundo o geógrafo Neil Smith (2015), que se dedicou à pesquisa de gentrificação, desde as décadas de 1950 e 1960, quando escrito por Ruth Glass, a gentrificação passou de um fenômeno local do mercado de moradia para sua ampliação nos anos 1980 através de processos de reestruturação urbana e econômica, e sua generalização nos anos 1990 como uma estratégia urbana neoliberal pelos circuitos globais de capital e circulação cultural. Smith (2012) ainda faz uma importante analogia entre processos de gentrificação e o avanço na fronteira de colonização no oeste estadunidense nos séculos XVIII e XIX. Para ele, embora não seja um avanço geográfico absoluto, o "avanço na fronteira da gentrificação" seria uma reconquista de territórios deprimidos de investimentos por bancos, promotores imobiliários, cadeias de distribuição, Estado etc. E essa "recolonização" é feita, geralmente, pela classe média de cor branca sobre população de baixa renda de cor não-branca.

Devido ao aumento de fenômenos semelhantes, outros pesquisadores também ampliaram e/ou adequaram a definição do conceito de gentrificação. A historiadora e crítica de arte Rosalyn Deutsche e a jornalista Cara Ryan (2015), na publicação The fine art of gentrification, descreve o processo de valorização imobiliária de Lower East Side em Nova York com a atração artistas e galerias de arte graças às campanhas realizadas pela Prefeitura. Jorge Sequera (2015) reconhece que a gentrificação pode ocorrer, por exemplo, com a entrada de novas atividades comerciais voltadas para a classe média. Mendes (2017, p. 491) denomina, como "gentrificação turística", a "transformação dos bairros populares e históricos da cidade/centro em locais de consumo e turismo, mediante a expansão da função de recreação, lazer ou alojamento turístico".

De modo mais abrangente, conforme definição de Simas (2018), entende-se gentrificação como um processo que converte um bairro desvalorizado, opção de moradia e de trabalho para população de baixa renda, em uma mercadoria valorizada a ser consumida pela classe média, empresas e turistas, ampliando assim a reprodução do capital na cidade em negócios turísticos, de entretenimento e/ou imobiliário. Em geral, este fenômeno é estimulado por iniciativas pública e/ou privada e está associado ao êxodo de grande parte da população de baixa renda para outras áreas desvalorizadas e periféricas. Esse êxodo pode acontecer de forma "silenciosa" devido ao aumento do custo de vida, sobretudo de aluguel ou de forma mais incisiva através de remoção e demolição de antigos cortiços, ocupações, vilas e prédios inteiros pelo poder público e/ou mercado imobiliário para construção de novos empreendimentos. Do ponto de vista do negócio, esse processo de segregação socioespacial passa a ser desejado para não "repelir" seus clientes, ou seja, a classe média, empresas e/ou turistas.

Neste sentido, são construídos espaços e paisagens voltados para o que Paola Jacques (2005) chama de cidade-espetáculo. Isso acontece com a intenção de produzir uma imagem da marca da cidade; de promover ao turista (e não o habitante) um certo padrão mundial de urbanização, de ho- 
téis, de fast food etc.; e a diminuição da participação popular. E isso pode acontecer através de duas correntes distintas de "não-cidade": pela difusão da cidade genérica, urbanização generalizada, cidades-shoppings e com apologia à escala do grande; ou por congelamento por uma cidade-museu, patrimonialização desenfreada ou cidade-parque-temático. Esse "processo de espetacularização urbana traz sempre consigo um tipo de gentrificação espacial" com uma estratégia mais subliminar de "expulsão dos mais pobres das áreas de intervenção" (ibid, p. 19).

No Brasil e demais países latino-americanos, segundo Joana Santana (2013), esse tratamento da cidade como um empreendimento foi impulsionado com grande importância pelo Banco Interamericano de Desenvolvimento (BID) que sob a aparência da diminuição da pobreza elaborou um modelo de gestão de cidades para tornar a administração municipal mais competitiva, atrair investimentos empresariais e realizar PPP. Sua contradição está na necessidade de embelezamento das cidades com intervenções urbanas segmentadas e focalizadas, como na renovação de áreas portuárias para consumo do turismo, que geram valorização do solo e gentrificação.

O Plano de Revitalização do Bairro do Recife é um desses exemplos que seguiu diversas estratégias do planejamento estratégico, desde PPP até o aquário (não executado), e ainda se tornou um marco por ser a primeira capital a angariar recursos diretamente do BID, independente do governo federal.

Metodologia

Esta investigação se faz necessária pela necessidade de costurar diferentes planos, projetos e impactos dentro do processo de transformação do Bairro do Recife como um todo. São diversos planos e projetos urbanos incidentes e suas análises cientificas geralmente são pontuais. Para tal, é realizada esta pesquisa exploratória que analisa as principais transformações urbanas e na população do Bairro do Recife desde os anos 1980. A coleta de dados foi feita através de pesquisas bibliográficas, documentais, por observação no local e entrevistas semiestruturadas a indivíduos maiores de 18 anos seguindo os critérios de: (1) população local (residentes e trabalhadores); (2) técnicos envolvidos com os projetos; (3) pesquisadores que realizaram algum tipo de investigação sobre o caso; e (4) movimentos de resistência. Por se tratar de uma pesquisa que envolve seres humanos, este projeto foi aprovado junto ao Comitê de Ética em Pesquisa do Hospital Universitário Clementino Fraga Filho da UFRJ, através da Plataforma Brasil, antes da ida a campo.

\section{Bairro do Recife}

O Bairro do Recife possui um território rico em história pelas suas diversas transformações, inclusive no período contemporâneo. Desde que se tornou deprimido de investimentos em meados do século XX, seu patrimônio edificado foi sendo sucessivamente reconhecido e mapeado pelos Plano de Desenvolvimento Integrado da Região Metropolitana do Recife em 1976; Plano de Preservação dos Sítios Históricos da Região Metropolitana do Recife em 1977; Decreto Lei no 13.957 de Proteção dos Sítios Históricos em 1979; e Zonas Especiais de Preservação do Patrimônio Histórico em 1981, 
que resultaram em incentivos fiscais (isenções de licença e IPTU) e na criação das Zonas de Preservação e de Preservação Ambiental em todo território do Bairro do Recife (PBR, 2016; PCR, 1981, 2001b; RECIFE, 1979). Apesar dos incentivos, a maior proteção e menor potencial construtivo afugentaram ainda mais o interesse do mercado imobiliário resultando em "um processo acelerado de degradação física e uma mudança de usos muito rápida, especialmente do comércio varejista e dos serviços especializados para o comércio ambulante e informal e os serviços pouco especializados" (ZANCHETI; LACERDA, 1998, p. 96). Com isso, o Bairro do Recife tinha seu patrimônio preservado por direito, mas não de fato.

A partir de então, são traçadas novas ações no Bairro do Recife, apresentadas nas seções a seguir: Plano de Reabilitação do Bairro do Recife em 1987, no qual alcançou-se importante conhecimento do território e de sua população; Plano de Revitalização do Bairro do Recife em 1992, elaborado para angariar recursos do Prodetur-BID, atração de investidores e turistas e que resultou maiores transformações no Polo Bom Jesus e Alfândega; Porto Digital em 2000, com a criação do parque tecnológico para atração de empresas e trabalhadores "criativos"; Projeto Porto Novo Recife em 2007, que junto do Recife Antigo de Coração consolidam o waterfront do Bairro do Recife em um espaço de entretenimento e turismo; e o Programa de Requalificação Urbanística e Inclusão Social da Comunidade do Pilar em 2002 que até então não foi concluído.

\section{Plano de Reabilitação do Bairro do Recife}

Na gestão do Prefeito Jarbas Vasconcelos (1986-1988), foram desenvolvidos o Plano de Reabilitação do Centro Expandido e, posteriormente, o Plano de Reabilitação do Bairro do Recife em 1987 para maiores foco e resultados. Esse plano teve forte caráter social, tanto pelo compromisso político quanto de seus técnicos. Suas referências foram experiências de reabilitação das áreas centrais de: Barcelona, que enfatizava o valor histórico cultural arquitetônico; e de Genebra, cujo foco era reocupação dos vazios para redução do déficit habitacional (Entrevista 22 - autora do Plano de Reabilitação). Sua elaboração se deu com um processo aberto de intervenção permanente com "técnicos vivendo/trabalhando no próprio bairro", graças à instalação na ilha do Escritório Técnico do Bairro do Recife, e com a participação e atuação de segmentos interessados, através de um Grupo Permanente de Debates (PCR, 1988, 2001b; VIEIRA, 2006).

\footnotetext{
A população era ouvida. Todos os segmentos. Ou seja, nós colocávamos no mesmo ambiente os representantes dos usineiros, (...) as prostitutas, os bancários, os comerciários, os que ainda existiam, os donos de bar, os sindicatos, os portuários. Então era um mesmo grupo. O que era fantástico porque as ideias foram surgindo. Ou seja, o Plano de Reabilitação se escreveu ao final do processo. (Entrevista 22, 30 out. 2017, autora do Plano de Reabilitação).
}

A etapa de diagnóstico identificou: 472 imóveis e 1001 unidades imobiliárias; 100\% de infraestrutura de abastecimento de água, rede de esgoto e rede elétrica, mas carente de manutenção e/ou modernização; a menor densidade habitacional do centro com 604 habitantes em 1980; a existência da Favela do Rato com uma das populações mais pobres do centro, com $68,1 \%$ com renda de 1 a 
3 salário-mínimo e 12,9\% sem qualquer tipo de renda (PCR, 1988).

Esse reconhecimento se traduziu em diversas propostas que conciliavam fomento à ocupação dos vazios, ao turismo, ao entretenimento e ao desenvolvimento endógeno a partir de melhores infraestruturas (cadastro arquitetônico, recuperação, reativação de linhas de bonde, pintura das fachadas, orientação técnica, equipamentos culturais etc.) e oportunidades para população local (registro da memória local, reforma de edifícios para implantação de centro profissionalizante, restaurante popular com boxes para trabalhadores informais e habitação de interesse social).

Dentre os principais impactos, destacam-se as primeiras ações de manuteção do espaço público e de eventos como serenata e o Circo Voador deram grande visibilidade. Com isso, algumas pessoas compraram imóveis e instalaram novos estúdio de dança, galeria de arte na Rua do Bom Jesus etc. E "o Bairro, que todo mundo desconhecia, passou a ser frequente na mídia" (Entrevista 22, 30 out. 2017, autora do Plano de Reabilitação). Alguns órgãos e secretarias públicas também passaram a se instalar e, com isso, restaurar propriedades do poder público (Entrevista 21, 30 out. 2017, técnico da Prefeitura). O projeto Memória em Movimento foi um dos poucos que tiveram prosseguimento com sua publicação através de livro ainda em 1989. É neste documento que se encontram dados importantes coletados através de entrevistas a atores locais. Ainda neste ano de 1989, foi escrito o Relatório de Atividades do Escritório que registra outras importantes considerações, como a falta de interesse de instituições nacionais e internacionais para restauro dos imóveis para habitação dos trabalhadores da noite (PCR, 1989, p. 27-9). Entretanto, "embora existissem recursos negociados para a implementação de vários dos projetos (...), a nova gestão [municipal] decidiu não implementá-los" (PCR, 2001b, p. 21).

Com o turismo como um dos pilares do plano econômico, o Governador Joaquim Francisco encomendou ao Prefeito Gilberto Paulo, em 1991, um novo planejamento do Bairro do Recife pelo potencial econômico de seu patrimônio histórico e artístico. Em 1992, foi elaborado o Plano de Revitalização do Bairro do Recife pelas empresas URBANA: Planejamento e Projetos, Borsoi Arquitetos Associados e Multi Programação Visual (ZANCHETI; MARINHO; LACERDA, 1998); com objetivo de captar empréstimo junto ao BID, dentro Programa de Desenvolvimento do Turismo (Prodetur) (PCR, 2001b). Nesses moldes, o Plano tinha como objetivo tornar o Bairro em um centro: "metropolitano regional"; de "atração turística nacional e internacional"; e de lazer e diversão "criando um espetáculo urbano" (AD/DIPER, 1992). A proposta seguiu as referências estadunidenses e europeias com as propostas de PPP, reforma do waterfront, aquário, preservação do patrimônio, espaços de consumo, lazer e entretenimento, equipamentos culturais e shopping center, conforme a Figura 1. 
Figura 1 - Plano de Revitalização do Bairro do Recife.

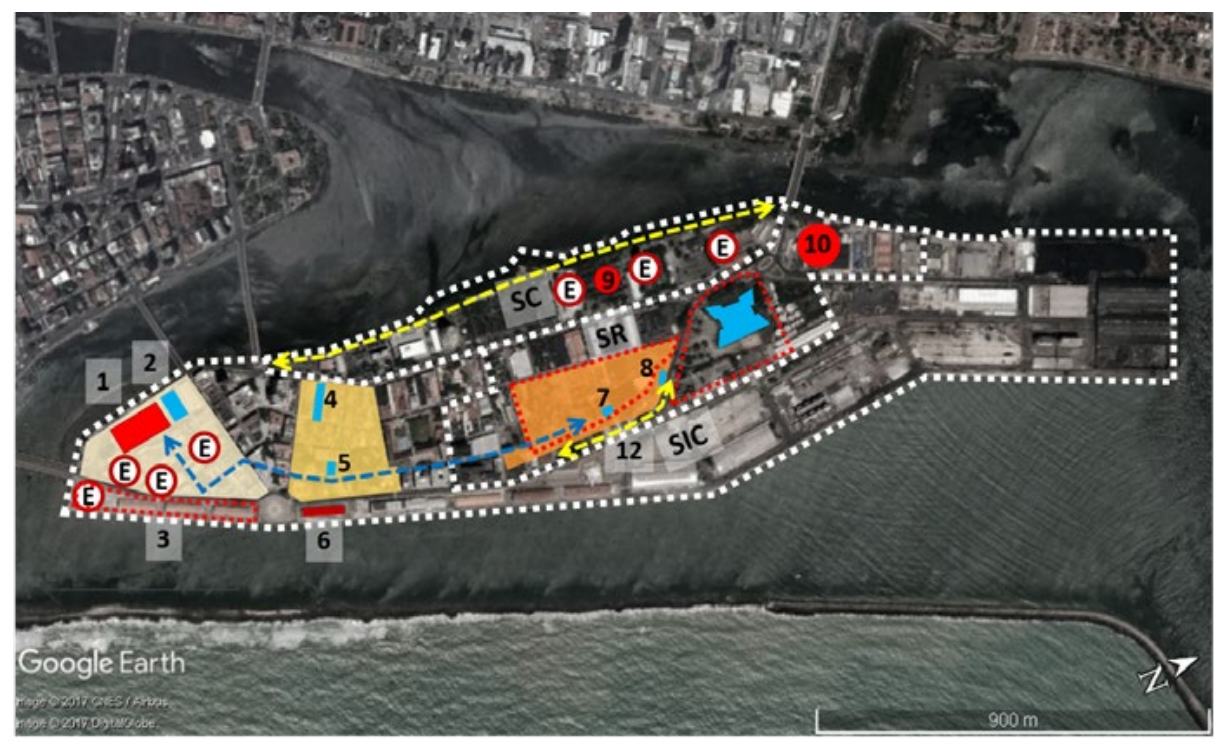

Legenda: (SIC) Setor de Intervenção Controlada; (SR) Setor de Renovação; (SC) Setor de Consolidação; (1) Shopping Paço Alfândega; (2) Igreja Madre de Deus; (3) waterfront; (4) Teatro Apolo; (5) Sinagoga; (6) Terminal Marítimo; (7) Igreja Nossa Senhora do Pilar; (8) Estação do Brum; (9) Aquário; (10) centro empresarial; (11) Forte do Brum; (12) Complemento da Av. Alfredo Lisboa.

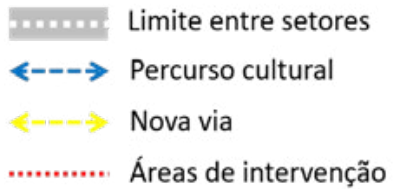

(E) Estacionamentos
Polo Alfandega

Polo Bom Jesus

Polo Pilar

Intervenções

Bens tombados

Fonte própria (2018).

Na sua segunda gestão municipal (1993-1996), Jarbas Vasconcelos abandona o Plano de Reabilitação elaborado em sua primeira gestão e dá prosseguimento ao Plano de Revitalização de seu antecessor. Sua prioridade é o Polo Bom Jesus, concebido como um "espaço de lazer, consumo e animação diurna/noturna" e com referência na animação cultural de Nova Orleans, Boston, Buenos Aires, Amsterdã (AD/DIPER, 1992); e do Pelourinho em Salvador como referenciava o Prefeito (Entrevista 20, 27 out. 2017, autor do Plano de Revitalização). Foram realizados diversos eventos através do poder público (Feira de Antiguidades, Réveillon, Carnaval, São João, Dançando na rua, Festival de seresta e Anos dourados); e contratada uma consultoria em administração e marketing para convencimento de investidores (ZANCHETI; LACERDA, 1998).

Contudo, esses estímulos não despertaram o interesse de proprietários e investidores na PPP. Os benefícios fiscais eram pequenos em relação ao custo de restauro de edifícios ecléticos, ainda mais quando muitos proprietários já não pagavam IPTU e não havia uma cobrança pela função social dos imóveis vazios (Entrevista 21, 30 out. 2017, técnico da Prefeitura). Para reverter este quadro, o poder municipal assumiu o papel que deveria ser da iniciativa privada na PPP com a desapropriação como utilidade pública de 05 imóveis na Rua do Bom Jesus, seu restauro e sua concessão à empresarios para bares e restaurantes com custo de aluguel reduzido. Assim, foi possível transformar a Rua Bom Jesus em um polo de entretenimento (ver Figuras 2 e 3). Essa animação foi irradiada para Rua do Apolo, por iniciativa privada, com novos bares e restaurantes. 
Figura 2 - Rua do Bom Jesus antes da intervenção.

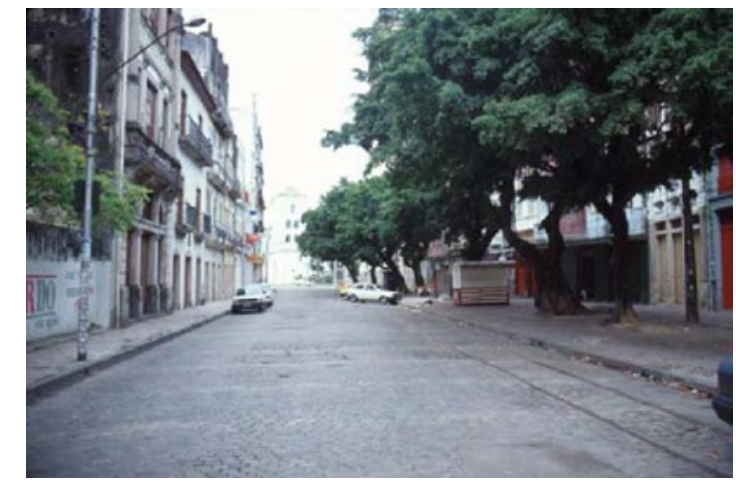

Fonte: Sílvio Zancheti, 1992 (VIEIRA, 2006, p. 120).

Figura 3 - R. Bom Jesus após o Cores da Cidade.

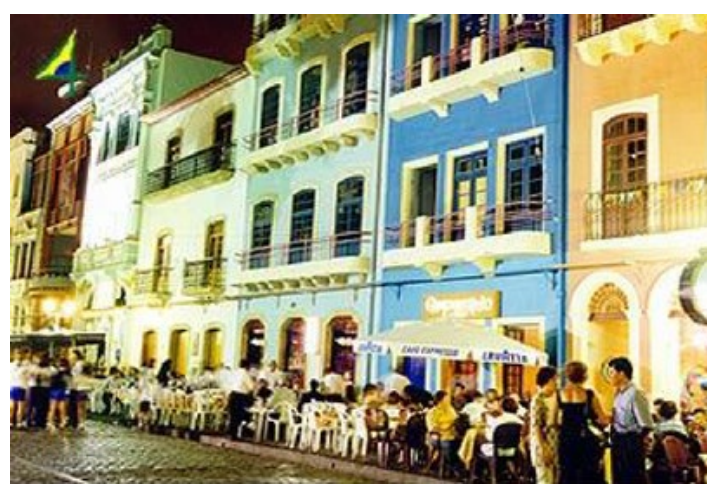

Fonte: Sec. de Cult. Turismo e Esporte (VIEIRA, 2006, p. 121).

No Relatório Final contratado pelo BID, entre 1993 e 1996, destacam-se a recuperação de $16.723 \mathrm{~m}^{2}$ de área construída e a valorização imobiliária de $+68 \%$ no Polo Bom Jesus, enquanto houve desvalorização de $-13 \%$ no Polo Alfandega e $-5 \%$ no Polo Pilar. Contudo, as novas atividades (bares e restaurantes) concentravam predominantemente no térreo, gerando um estoque ocioso nos pavimentos superiores de $17,8 \%$ do construído no Polo Bom Jesus. Em relação à manutenção do espaço do Bairro do Recife, houve um aumento de $\mathrm{R} \$ 1.185 .947$ para $\mathrm{R} \$ 1.600 .999$. Na arrecadação de impostos, houve diminuição de 13,1\% de IPTU devido às isenções e aumento de 632,4\% de Imposto de Transmissão de Bens Imóveis (ITBI) e 76,6\% de Imposto Sobre Serviços (ISS) (ZANCHETI; LACERDA, 1998).

Na gestão seguinte, do Prefeito Roberto Magalhães (1997-2000), foi elaborada uma proposta de operação urbana (Lei 16.290/1997) que logo se torna obsoleta devido à aprovação, em 1998, do Tombamento do Patrimônio do Núcleo Original da Cidade do Recife Dentro de Portas. Esse título, por sua vez, contribuiu para captação de recursos através do Programa Monumenta/BID. Nesse contexto, surgem novos equipamentos culturais e investimentos em infraestrutura pontuais na Ilha, sobretudo no Marco Zero e no Polo Alfândega (PCR, 2001b).

A cientista social Júlia Morim de Melo (2003) constatou que, para alguns trabalhadores do por- 
to entrevistados entre os anos de 2001 e 2003, essa revitalização foi boa, pois diminuiu a violência e aumentou a autoestima, apesar de não utilizar os serviços (bares) do Polo Bom Jesus. Ela levantou que ainda havia 9 casas de cômodos e 1 cortiço que totalizavam 58 indivíduos; uma população temporária que possuía residência fixa em outro local; e 1 boate de prostituição e pensões que poderiam alugar quartos para realizar tais programas. No entanto, a valorização estava resultando no êxodo de parte da população local, em sua maioria "de prostitutas sobreviventes da decadência do porto" (MORIM DE MELO, 2003, p. 12). Ela registrou algumas manchetes sobre este processo na Folha: "Bairro do Recife vive metamorfose diária" em 1997 e "prostituição perde espaço para o lazer" em 1998.

Para Leite (2006), essa revitalização da parte sul da Ilha como um empreendimento voltado à política de enobrecimento, ao "espaço do espetáculo" e a um complexo mix de consumo e entretenimento. De um local de prostituição, o Bairro se tornou em uma área de maior concentração de bares e restaurantes, com intensa programação cultural (shows, apresentações de dança, exposições de arte etc.) e de festividades de carnaval e de São João. Isso demonstra, para o autor, que a intervenção tornou o patrimônio em mercadoria, esvaziou os sentidos habitacionais e sociais e repercutiu em processos de exclusão social.

Em relação ao perfil populacional, entre os Censos 1991 e 2000, o Bairro do Recife aumentou de 565 para 925 habitantes, de 76 para 288 domicílios e de $42,28 \%$ para $27,12 \%$ de analfabetismo (ADHR, 2005). Há relatos sobre algumas pessoas que foram atraídas para morar no Bairro neste período, principalmente artistas e arquitetos (Entrevista 15, 24 out. 2017, residente do Bairro do Recife). A Favela do Rato também cresceu. Em 2002, somava 463 habitações (sendo 82\% em logradouro público), sem esgotamento sanitário, com baixa renda ( $75 \%$ com renda de até 2 salários mínimos), com muitos trabalhadores do centro (72\% trabalhava na área ou no entorno), 32\% de analfabetos e com casos de tuberculose (LACERDA, 2007). Esse crescimento da Favela do Rato inviabilizou a proposta habitacional do Plano de Reabilitação, que se mantinha no Plano de Revitalização. Com isso, em 1998, uma nova proposta de habitação social foi elaborada, mas também não foi executada. As únicas transformações foram a implantação de uma escola em 1997 e, a pedido dos moradores, em seu nome que passou de Favela do Rato para Comunidade do Pilar (NERY; CASTILHO, 2008).

\section{Porto Digital}

Embora a concepção de um parque tecnológico em Tecnologias da Informação e Comunicação (TIC) tenha nascido no Centro de Informática (CIn) da Universidade Federal do Pernambuco (UFPE), esta proposta foi ao encontro do planejamento do Bairro do Recife. Em vez da entrada de residentes de classe média, investir-se-ia na atração de empresas e trabalhadores de classe média para adquirir e custear a revitalização dos imóveis tombados. Nesses moldes, a proposta do Porto Digital foi muito bem aceita entre acadêmicos, atores privados e públicos e sobretudo por Jarbas Vasconcelos que tinha sido então eleito como governador de Pernambuco (1999-2006). Em 2000, foi criada a política estadual do Porto Digital com os objetivos de "inserir Pernambuco no cenário 
tecnológico e inovador do mundo" e contribuir com a revitalização econômica e urbana do Bairro do Recife, com a qualificação, em 2001, da Associação Núcleo de Gestão do Porto Digital como Organização Social (OS) responsável por implantar o modelo de governança, promover a infraestrutura e instalar a incubadoras no Bairro do Recife.

Um dos primeiros impactos da implantação do Porto Digital foi a transferência de empresas e de riquezas de uma parte da cidade para outra (Entrevista 20 - autor do Plano de Revitalização). Entretanto, o Porto Digital foi se consolidando com um novo perfil de governança voltado para os negócios imobiliários.

Isso porque, em 2006, no último ano da gestão estadual de Jarbas e de seu vice José Mendonça Filho, a antiga Sede do BANDEPE foi concedida à OS do Porto Digital para gerar renda através do aluguel de grande parte dos $11.700 \mathrm{~m}^{2}$ a empresas "embarcadas" no Porto Digital e, com isso, garantir sua sobrevivência na mudança política (RECIFE, 2006a; Entrevista 09, 23 out. 2017, técnico do Projeto Porto Novo Recife). Nesse mesmo ano, foi estabelecida a redução de $60 \%$ na alíquota do ISS (de $5 \%$ para $2 \%$ ) para as empresas "embarcadas" instaladas no Bairro do Recife (RECIFE, 2006b). Em 2008, o Porto Digital foi reconhecido pelo Ministério do Desenvolvimento, Indústria e Comércio Exterior como um Arranjo Produtivo Local (APL). Com isso, a OS passou a receber apoio para política pública a nível federal, ampliando seus "recursos de emenda de bancada, de FINEP, de Ministério de Cultura, de BNDES", mas, por outro lado, foi se tornando cada vez mais distante dos compromissos sociais, delegando esta responsabilidade às empresas "embarcadas" sendo um dos quesitos para concessão do selo Porto Digital (Entrevista 08, 20 out. 2017, técnico do Porto Digital).

Nesses moldes, em 2011, 58,2\% de suas fontes de recursos vinham da remuneração dos imóveis (PD, 2011). No total, a OS está gerindo imóveis que somam aproximadamente $33.685 \mathrm{~m}^{2}$ (sendo $24.037 \mathrm{~m}^{2}$ em concessão estadual e $9.648 \mathrm{~m}^{2}$ em sua propriedade) (ALBUQUERQUE; LACERDA, 2017). O portfólio de espaços para aluguel do Porto Digital é apresentado inclusive em eventos nacionais e internacionais; demonstrando assim que "a face da moeda representada pelos coadjuvantes efeitos rentistas - bastante sedutores - provavelmente brilha mais aos olhos de setores da gestão e operação do parque do que a face da elevação das competências inovativas das empresas que ali decidem se instalar" (LACERDA; FERNANDES, 2015, p. 350). Para alguns entrevistados, o Porto Digital se tornou um "corretor de luxo para atividades TIC", um "agente imobiliário" ou uma "grande imobiliária" (Entrevistas 16, 25 out. 2017, residente do Bairro do Recife e 21, 30 out. 2017, técnico da Prefeitura). A Figura 4 indica no Bairro do Recife os imóveis adquiridos, concedidos ou relacionados ao Porto Digital. 


\section{Figura 4 - Localização dos edifícios relacionados ao parque tecnológico Porto Digital.}

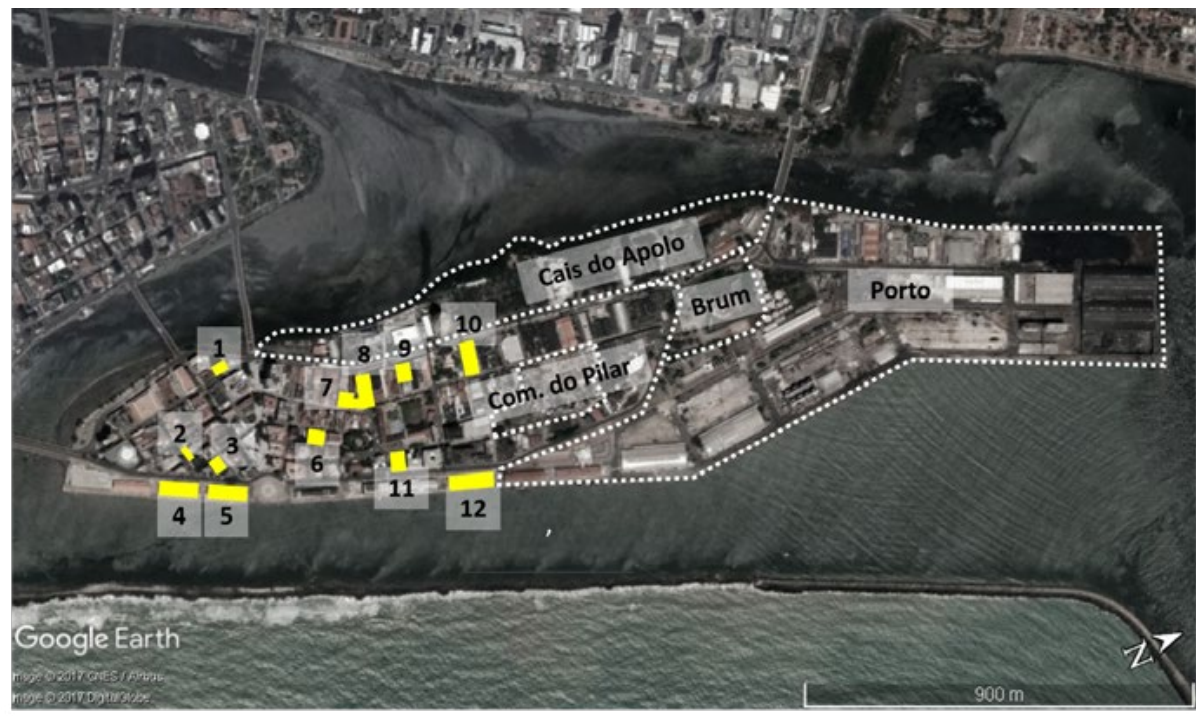

Legenda: (1) Ed. BANDEPE; (2) Moeda, 50; (3) Maria César, 68; (4) Armazém 13; (5) Armazém 12); (6) ITBC/SOFTEX; (7) Ed. Cais do Porto; (8) Ed. Apolo 213 e 215; (9) Cais do Apolo 181; (10) CESAR; (11) SECTMA; e (12) Armazém 9.

Principais edifícios ligados ao parque tecnológico

Outras delimitações

Fonte própria (2018).

Entre os Censos 2000 e 2010, há uma diminuição de 925 para 602 habitantes e de 288 para 198 domicílios (ADHR, 2005; PCR, 2016a). Por outro lado, houve entrada de população trabalhadora desse parque tecnológico. O perfil de escolaridade desses trabalhadores é de $66,9 \%$ com superior completo (sendo 18,7\% com especialização, 6\% com Mestrado e 1\% com Doutorado) e 85,3\% com conhecimento em inglês; sendo que $29,6 \%$ das empresas possuem professores universitários em seus quadros de funcionários. A maior parte dos trabalhadores $(55,1 \%)$ tem idade entre 22 e 29 anos e 78,3\% é empregada por CLT/pessoa física (PD, 2012). Conforme Tabela 1, observa-se em quase todas as áreas a maior remuneração aos profissionais do sexo masculino. Esta Tabela explana ainda áreas que não são "criativas" ou não lidam com alto grau de conhecimento, como operador de telemarketing. Mas tais atividades são computadas para engrossar o quadro de postos de trabalhos e para apresentar um suposto sucesso inovativo ou criativo do parque tecnológico.

Tabela 1 - Média salarial por sexo e por área dos trabalhadores do Porto Digital

\begin{tabular}{|llll|}
\hline Área & Feminino & Masculino & Razão Masc./Fem. (\%) \\
\hline Operador de Telemarketing & 661,60 & 817,56 & $123 \%$ \\
\hline Estagiário & 765,35 & 781,29 & $102 \%$ \\
\hline Administrativa & $1.721,32$ & $1.366,57$ & $79 \%$ \\
\hline Vendas & $2.816,67$ & $3.195,71$ & $113 \%$ \\
\hline Técnica & $2.519,14$ & $2.551,94$ & $101 \%$ \\
\hline $\begin{array}{l}\text { Gestão } \\
\text { Fonte:PD, 2012, p.55 }\end{array}$ & $4.763,04$ & $5.772,82$ & $121 \%$ \\
\hline
\end{tabular}


Embora não se trate de ação incisiva do Porto Digital, é bastante simbólica a transformação do atual Edifício Apolo 235 do Porto Digital que fora nos anos 1980 a Pensão "Convento" que abrigava alguns dos "aposentados da 'batalha' da vida naquele sítio histórico" (PCR, 1989, p. 23), conforme Figuras 5 e 6.

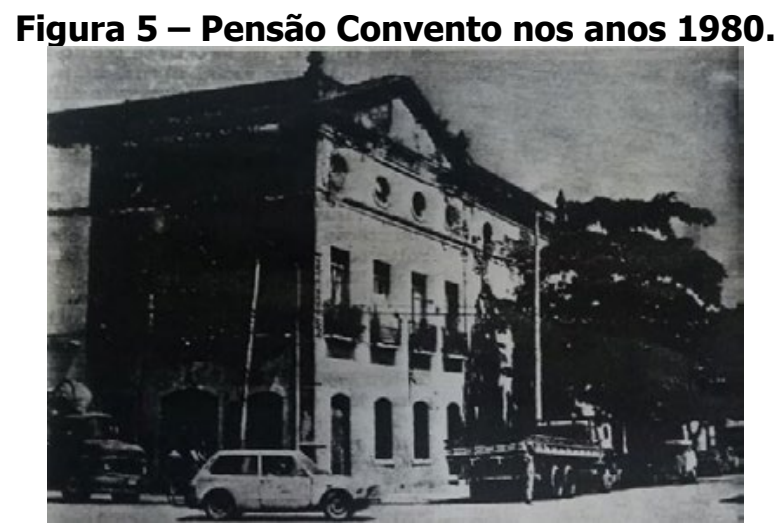

Fonte: PCR, 1989, p. 22.

Figura 6 - Edifício Apolo 235 inaugurado em 2017.

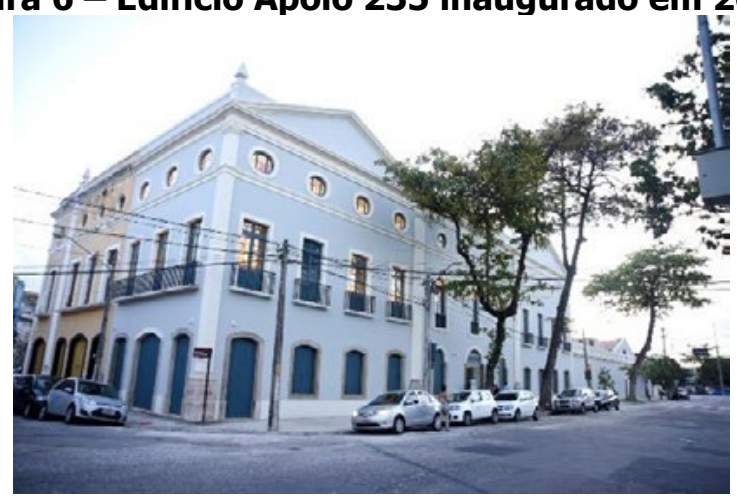

Fonte: PD, 2017.

É simbólico também o depoimento de Francisca Lopes Gomes, uma de suas antigas moradoras, sobre este processo de gentrificação que ainda estava por vir:

E um Convento como esse que podia ficar tão bonito, com as velhas, com esse povo mais cansado morando lá no seu cantinho, de um jeito decente, e no andar de baixo aquelas coisas bonitas, folclóricas, tudo cheio de luz, de animação para quem quiser ver. Cadê a força de dona Prefeitura? De dona LBA? Cadê a força do governo? (...) Será que eu nasci aqui e na hora que esse bairro vai se embelezar não vai ter um canto para mim? (MONTENEGRO; SALES; COIMBRA, 1989, p. 42).

Projeto Porto Novo Recife

Em 2007, no governo de Eduardo Campos (2007-2014), foi constituído o Núcleo Técnico de Operações Urbanas que, em um contexto de candidatura de Recife como cidade-sede da Copa do 
Mundo de 2014, elaborou uma proposta sobre o território portuário: o Projeto Porto Novo Recife. Este projeto tem como abrangência as áreas não operacionais do Porto do Recife com o paradigma de PPP criando oportunidades de negócios à iniciativa privada, desde estacionamento no espaço público até hotéis de "nível internacional" (BRANDÃO; NASCIMENTO; CARVALHO, 2012). Entretanto,

E aí apareceu um grande grupo interessado em fazer tudo [do Projeto Porto Novo Recife]. Então o governo não entrava com dinheiro pra fazer. Só que no início tudo bem, achou o projeto ótimo. Mas quando eles ganharam a ideia, aos poucos eles começaram a fazer a cara do que eles queriam. Aí é o ponto de vista do lucro, do empreendimento, e a coisa foi se descaracterizando. (Entrevista 09, 23 out. 2017, técnico do Projeto Porto Novo Recife).

Como exemplo dessa "descaracterização", destaca-se a proposta de ciclovia, renques de árvores, grandes canteiros gramados e até um balão para avistar a planície de Recife (ver Figuras 7 e 8) que resultou em um estacionamento de dois pavimentos (um semienterrado e outro elevado).

Figura 7 - Proposta de espaço público na foz do rio.

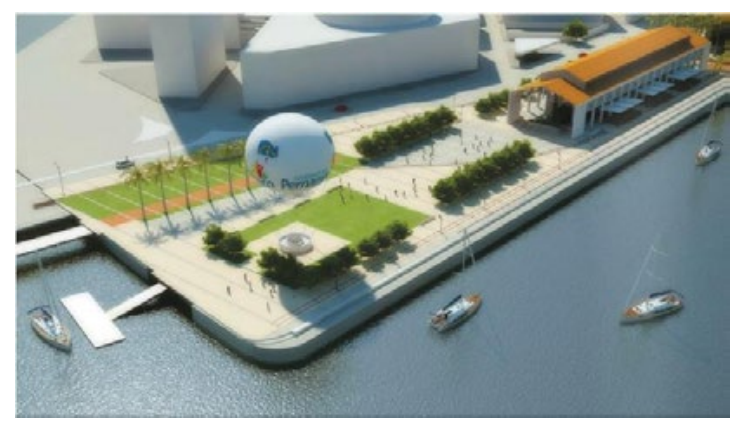

Fonte: BRANDÃO, NASCIMENTO e CARVALHO, 2012, p. 133.

Figura 8 - Estacionamento construído na foz do rio.

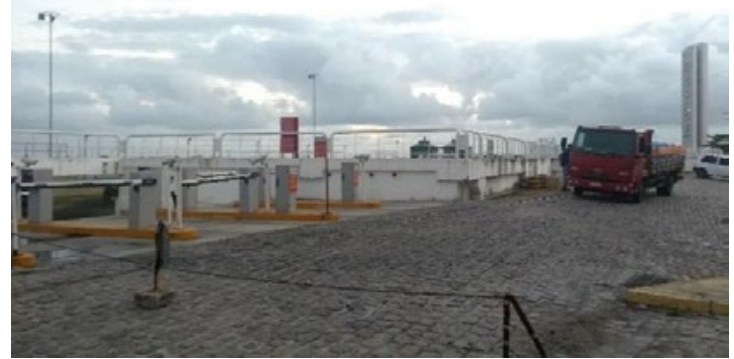

Fonte própria (2017).

Nos Armazéns 12 e 13, foram inaugurados, em 2014, bares e restaurantes que foram ambientados de tal modo que o usuário (consumidor de classe média) não se reconheça dentro de um armazém portuário, mas sim inserido em qualquer cenário genérico, dependendo da proposta do restaurante. Os armazéns se "abrem" ao waterfront, mas se "fecham" para Avenida Alfredo Lisboa com uma fachada com poucos "olhos para rua" e maior exposição de propaganda. E o pavimento 
superior, foi destinado às empresas "embarcadas", garantindo ali a presença da "classe criativa" e da classe média. O Armazém 11 se tornou o Centro de Artesanato de Pernambuco em 2012. O Armazém 10 foi demolido para construção do Museu Cais do Sertão, inaugurado em 2014. No Armazém 9, todo o pavimento térreo foi destinado a estacionamento e o pavimento superior a empresas "embarcadas" no Porto Digital. Em 2013, foi inaugurado o Terminal Marítimo de Passageiros no Armazém 7 ao norte da ilha com a construção de um anexo (ver Figura 9). Para efeito de comparação, do outro lado da rua, está a escola para a Comunidade do Pilar, que na década de 1990 a própria prefeitura dizia que funcionava em instalações provisórias (PCR, 2002), conforme Figura 10.

Figura 9 - Edifício anexo ao Terminal Marítimo de Passageiros no Armazém 7.

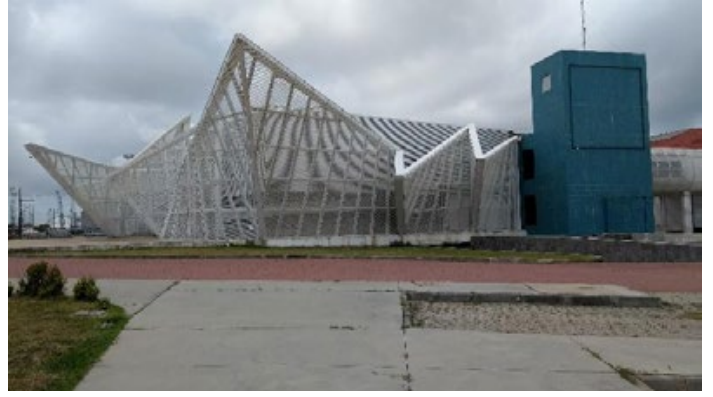

Figura 10 - Escola que atende a população da Comunidade do Pilar.

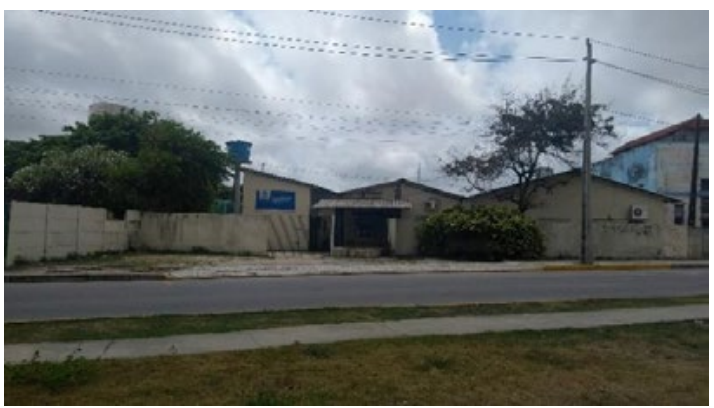

Fonte própria.

Em relação as transações de imóveis por ITBI no Bairro do Recife, são apresentados sua localização e seu número absoluto por uso do período entre 2008 e 2013, quando são maiores os recursos do Porto Digital e as obras do Porto do Recife, conforme Tabela 2 e Figura 11. 
Figura 11 - Localização dos imóveis

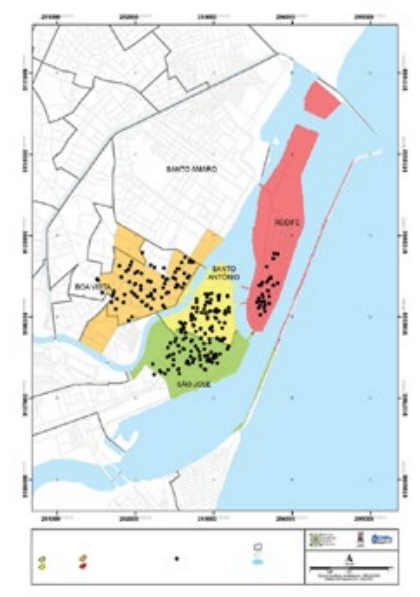

Tabela 2 - Imóveis transacionados no Bairro do Recife

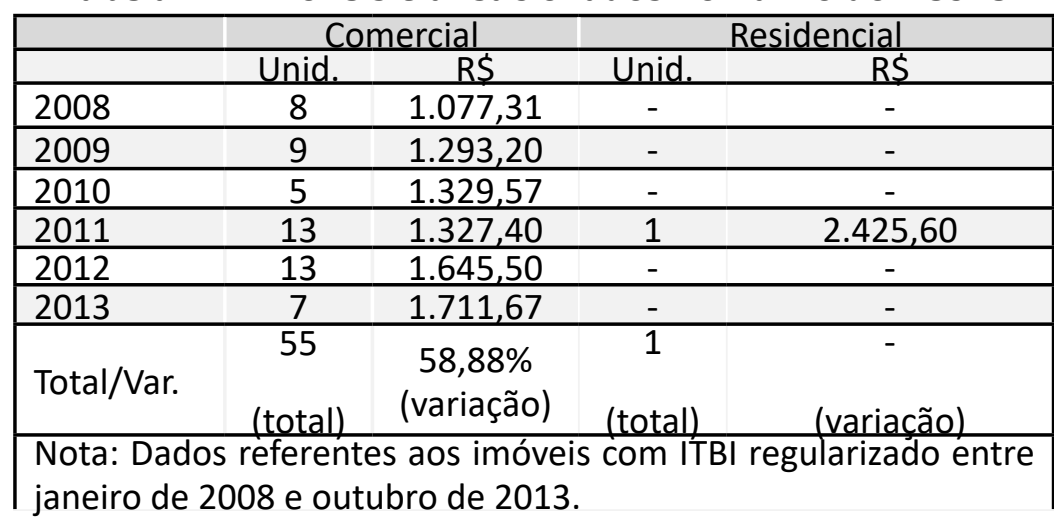

Fonte: Transações de Compra e Venda ITBI/PCR (LACERDA; ANJOS, 2015).

O Bairro do Recife teve somente a transação de um imóvel residencial em contraste aos 55 imóveis comerciais que em sua maioria se localizam ao sul da Ilha. Em relação a valores, o Bairro do Recife mantém um ritmo de valorização. Para Bernardino e Lacerda (2015), essa valorização no Bairro do Recife está diretamente ligada à implantação do Porto Digital. O que confirma o processo de gentrificação.

Em relação aos eventos, a partir da gestão do Prefeito Geraldo Júlio (2013-atual), foi lançado o Programa Recife Antigo de Coração em 2013. Com isso, o Bairro do Recife se tornou novamente um "grande parque a céu aberto", após o corte em eventos nas gestões anteriores. Dentre os novos investimentos, foi inaugurado em 2017 o boulevard da Avenida Rio Branco que apresentava uma apropriação desse espaço principalmente no final do expediente e aos domingos para atividades físicas e artísticas. Em relação à segurança, há alguns relatos de abusos nas medidas de segurança da Ilha, como o controle por detector de metais nas pontes e proibição de venda de bebidas em garrafas de vidro e de menores de idade sem a presença de responsáveis (DU, 2017a). "Tá! Mas pera aí, quem são essas pessoas que estão sendo revistadas? Porque branco e louro não vai ser!" (Entrevista 05 - trabalhadora em empresa "embarcada" no Porto Digital). 
Programa de Requalificação Urbanística e Inc. Social da Comunidade do Pilar

Com o crescimento da Comunidade do Pilar, na gestão do Prefeito João Paulo (2001-2008), foi elaborada uma nova proposta: o Programa de Requalificação Urbanística e Inclusão Social da Comunidade do Pilar, em 2002, com 420 moradias, com equipamento comercial, creche, uma nova escola, posto de saúde, posto policial, uma praça e a reforma do largo da Igreja do Pilar (MORIM DE MELO, 2003). Entretanto, o projeto não saiu do papel porque, segundo Nery $(2012$, p. 66), o Porto do Recife, então estadualizado, apresentou o interesse na área do projeto.

Somente em 2007, na gestão do governador Eduardo Campos, "a cessão de uso dos terrenos onde estão os moradores do Pilar passa do Porto para a Prefeitura do Recife" (NERY; CASTILHO, 2008, p. 25-29). Entretanto, o projeto precisou ser alterado novamente em 2008 pelo crescimento de sua população e pela maior área de trabalho, contemplando 588 unidades habitacionais (de 39 a $\left.41 \mathrm{~m}^{2}\right)$, infraestrutura urbana, escola, creche, posto de saúde da família, mercado público e ações de Desenvolvimento Comunitário. Foram considerados também a obrigatoriedade de acompanhamento arqueológico e o restauro da Igreja Nossa Senhora do Pilar (concluído em 2013). As obras das habitações começaram em janeiro de 2010, na gestão do João Costa (2009-2012), quando foi entregue somente um edifício habitacional (Bloco C) em setembro de 2012 com 48 moradias (NERY, 2012).

Na gestão do Prefeito Geraldo Júlio (desde 2013), encontraram, em 2013, vestígios de práticas funerárias nas escavações e prospecções arqueológicas que respondem por parte do atraso das obras. Em 2017, das 588 unidades habitacionais previstas, 192 tinham sido entregues; sendo que havia famílias que não tinham retornado, das 468 desalojadas em 2010 para realização das obras (DU, 2017b). Ou seja, em 10 anos, desde a última versão de projeto, o Programa entregou quase um terço das moradias, sem os demais equipamentos previstos, contrastando com o restauro da Igreja do Pilar concluído em 2013 (ver Figuras 12 e 13).

Figura 12 - Comunidade do Pilar.

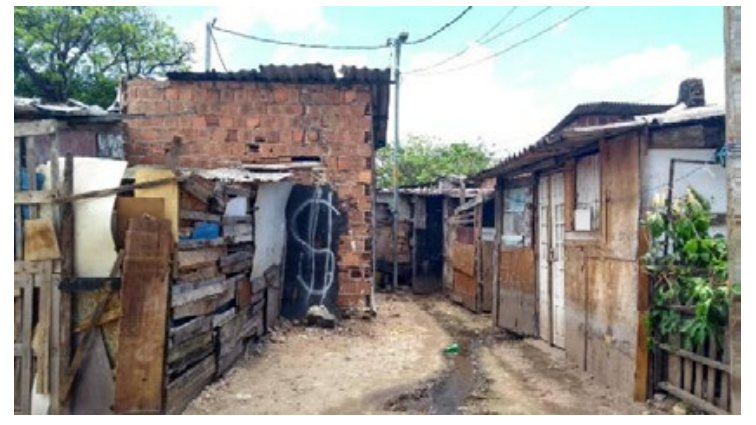

Fonte própria. 
Figura 13 - Comunidade do Pilar.

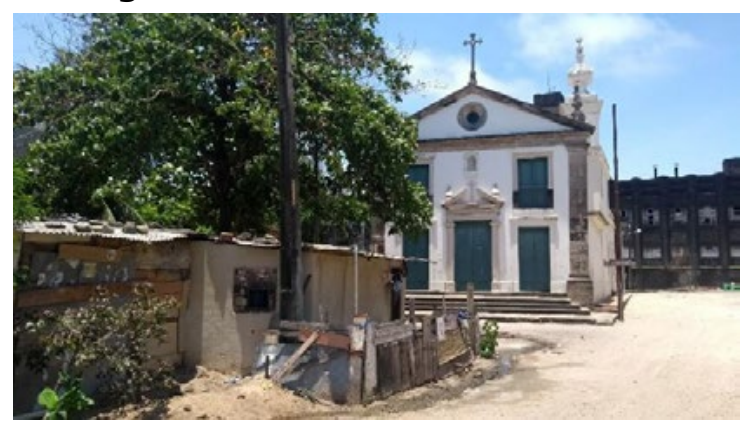

Fonte própria.

Em relação à sua população, ainda na etapa preliminar de revisão bibliográfica e documental, a pesquisa tinha encontrado uma incoerência de dados entre a população do Bairro do Recife e da Comunidade do Pilar. Enquanto o Censo de 2010 apontava uma população de 602 habitantes para o Bairro do Recife inteiro, outras pesquisas apontavam só para Comunidade do Pilar uma população de 1.832 habitantes em 2007. Ou seja, com uma diferença de três anos, a Comunidade teria três vezes mais a população do Bairro no qual está inserida. Em relação ao território, vale ressaltar que a Comunidade do Pilar não é uma ZEIS, outro bairro ou sub-bairro; e sim um território pertencente ao Bairro do Recife. Através de visita à URB, sua Equipe Social disponibilizou para consulta no local dois cadastros das famílias da Comunidade do Pilar nos anos de 2007 e 2012 e o Diagnóstico socioeconômico da Comunidade do Pilar de 2012. Com isso, foi levantado que, em 2007, a Comunidade do Pilar era composta por 459 núcleos familiares e 727 habitantes; demonstrando que existia um superdimensionamento de sua população nas estimativas anteriores. Em 2012, eram 566 núcleos familiares e 1.069 habitantes, sendo 207 núcleos recebendo auxílio moradia e por isso não moravam ali naquele momento. Assim, subtraindo as famílias com auxílio moradia, estima-se que 671 habitantes faziam parte dos 349 núcleos familiares que não recebiam auxílio moradia e por isso ali estariam vivendo. Esta estimativa foi feita através de regra de três simples que dá uma média de 1,9 pessoa por domicílio. Vale ressaltar que os núcleos familiares da Comunidade do Pilar iam até 09 pessoas (0,20\% das famílias), em 2012, mas sua grande maioria era composta por uma única pessoa $(46,62 \%)$, seguida por duas pessoas $(22,13 \%)$, por três pessoas $(17,21 \%)$ e por quatro pessoas $(8,40 \%)$ (PCR, 2012).

Isso demonstra que a diminuição da população do Pilar de 727 para 671 habitantes, entre 2007 e 2012, faz parte da remoção temporária de famílias para construção dos novos blocos, embora o número de famílias cadastradas tenha aumentado de 459 para 556 (consulta a dados da Equipe Social da URB; PCR, 2012). Sobre o perfil dos chefes dos núcleos familiares, $59,72 \%$ são mulheres e $76,45 \%$ tem até 25 anos. Há uma predominância de 53,50\% dos chefes de família com fundamental incompleto, seguida por $15,89 \%$ com médio completo, $10,05 \%$ com fundamental completo, $8,41 \%$ com médio incompleto e 6,54\% analfabetos. Em relação à ocupação, 29,38\% tem trabalho autônomo, avulso ou biscate; 25,82\%, emprego formal; $15,17 \%$, bolsa família; $14,25 \%$, aposentadoria, pensão e BPC/LOAS; e 12,17\% sem renda. Sobre renda, 59,05\% das famílias tem renda mensal de 
01 salário mínimo; 28,81\%, entre 01 e 02 salários mínimos; e 9,52\% sem renda (PCR, 2012).

\section{Discussão}

Gentrificação se tornou uma estratégia urbana neoliberal cada vez mais observada, inclusive em países periféricos, e com discursos cada vez mais elaborados. O Bairro do Recife é alvo de muitas estratégias que demonstram essa evolução e o direcionam para sua gentrificação. As transformações ocorridas nessas últimas décadas apresentam complexidade devido aos diversos atores (municipal, estadual e OS) e aos inúmeros programas, projetos e planos incidentes. Assim, apesar das análises pontuais de alguns projetos, havia uma lacuna na observação desse processo como um todo. Dentre os principais resultados, é possível observar, neste trabalho, os principais impactos das diversas ações no Bairro do Recife.

Nos anos 1980, o Plano de Reabilitação resultou em impactos menores e efêmeros, mas de grande importância sobre o conhecimento de sua população, inclusive a Favela do Rato que até então não constava nos registros municipais.

Nos anos 1990, com o plano de revitalização e o tombamento, os Polos Bom Jesus e Alfândega no Bairro do Recife passaram por valorização imobiliária, perderam parte de sua população de baixa renda e parte de sua identidade de trabalhadores portuários e de prostituição para se tornar em uma nova imagem (ou um cartão-postal). Em outras palavras, o Bairro do Recife é promovido em uma "cidade-espetáculo" tal como Paola Jacques (2005, p. 16-9) define: a intenção de produzir uma imagem/marca da cidade; de promover ao turista (e não o habitante) um certo padrão mundial de urbanização, de hotéis, de fast food etc.; e da "patrimonialização desenfreada" que resultam na "gentrificação espacial" com uma estratégia mais subliminar de "expulsão dos mais pobres das áreas de intervenção".

Em 2000, com a implantação do Porto Digital, o Bairro do Recife vai se consolidando com a entrada de empresas e da classe média trabalhadora, na figura da "classe criativa". O desconto em ISS, além da renúncia fiscal, aumenta as assimetrias no mercado, pois outros estabelecimentos "não criativos", como mercado, academia, papelaria etc., são desfavorecidos por pagar integralmente imposto. Inicialmente, houve transferência de empresas de outras partes da cidade para o Bairro do Recife. Para a cidade, trata-se de um modelo mais setorizado. Para a gentrificação do Bairro do Recife, a transferência de empresas significou transferência de riquezas. Posteriormente, a OS do Porto Digital se torna administradora de muitos imóveis concedidos ou adquiridos com fim na renda imobiliária de aluguel. Isso contribui para reabilitação dos edifícios históricos e para a imagem de Recife mais competitiva na atração de investimentos. No entanto, não são estabelecidas cotas para outras atividades, sobretudo para habitação de interesse social, que pudesse promover uma cidade mais compacta e menos desigual.

Em 2007, com foco no "Padrão FIFA", é desenvolvido o Projeto Porto Novo Recife e concedido à iniciativa privada que promove, principalmente, os Armazéns Portuários em espaços de consumo e entretenimento para turistas e classe média que se configura como um cenário "genérico" que não condiz com a realidade de Recife e sem previsão de novas escolas, bibliotecas, habitação de 
interesse social ou outras necessidades da população. Junto da campanha Recife Antigo de Coração, a fronteira de gentrificação avança nesse trecho do waterfront com eventos, aumentando as desigualdades e demarcando as barreiras socioespaciais no Bairro do Recife. Ao observar o todo, esses processos de gentrificação realmente aparentam se comportar, tal como conceituado por Neil Smith (2012: 20-52), com "avanços na fronteira da gentrificação". Aos poucos, os territórios deprimidos de investimentos são "reconquistados", neste caso específico, por promotores imobiliários, empresas, "classe criativa" e a própria OS do Porto Digital que é uma grande administradora/proprietária de imóveis e agente do planejamento urbano.

Em contraste com tantos investimentos, a Comunidade do Pilar é mantida sem a conclusão do Programa de Requalificação Urbanística e Inclusão Social da Comunidade do Pilar de 2002. É contraditório que a mesma gestão estadual tenha concedido o edifício BANDEPE à OS do Porto Digital e negado a cessão do terreno para realização do projeto para a Comunidade. Além disso, embora sejam fontes diferentes, a conclusão do restauro da Igreja do Pilar em um entorno carente de infraestruturas da Comunidade expressa novamente essa "patrimonialização desenfreada" frente ao direito à cidade pela população de baixa renda. Assim, a falta de interesse e a própria remoção temporária aumentam a vulnerabilidade sobre a sobrevivência dessa Comunidade nesse território.

A Tabela 3 resume a evolução do perfil populacional no Bairro do Recife nessas últimas décadas. Entre as décadas 1980 e 1990, observa-se uma queda na população que pode ser consequência do Plano de Reabilitação, mas é algo que carece de maior investigação pois os dados são insuficientes. Entre 1991 e 2000, é notório o crescimento da população do Bairro do Recife como um todo que se deve tanto à Comunidade do Pilar quanto à habitação formal. No entanto, há relatos sobre algumas pessoas que foram atraídas para morar no Bairro neste período, principalmente artistas e arquitetos, mas não se adaptaram pela sua transformação em uma área de eventos, com muitos shows, música alta, pessoas embriagadas e ruas sujas nos dias seguintes aos eventos (Entrevista 15 - residente do Bairro do Recife). Entre 2000 e 2010, a diminuição das habitações formais no Bairro reforça esse processo de êxodo e é também a outra face do crescimento do Porto Digital e sua grande metragem quadrada em escritórios. Além disso, a diminuição da população do Bairro do Recife se deve em parte às remoções na Comunidade do Pilar que promovem um "êxodo temporário". 
Tabela 3 - Evolução demográfica no Bairro do Recife e na Com. do Pilar

\begin{tabular}{|c|c|c|c|c|c|c|}
\hline & B. Recife & B. Recife & B. Recife & Pilar & B. Recife & Pilar \\
\hline & 1980 & 1991 & 2000 & 2007 & 2010 & 2012 \\
\hline População (1) & 604 & 566 & 925 & 727 & 602 & 671 \\
\hline menos de 15 anos & - & $25,4 \%$ & $35.0 \%$ & - & $31.06 \%$ & $48.92 \%$ \\
\hline 15 a 64 anos & - & $71,6 \%$ & $61,4 \%$ & - & $63,95 \%$ & $48,07 \%$ \\
\hline 65 anos ou mais (2) & - & $2,8 \%$ & $3,6 \%$ & - & $4,98 \%$ & $2,01 \%$ \\
\hline Famílias cadastradas & - & - & - & 459 & - & 556 \\
\hline $\begin{array}{l}\text { Beneficiadas com } \\
\text { aux. moradia }\end{array}$ & - & - & - & - & & 207 \\
\hline \multicolumn{7}{|c|}{$\begin{array}{l}\text { Elaboração própria com dados das seguintes fontes: nos anos } 1980 \text { - PCR (1988, p. 16-20); } \\
\text { nos } 1991 \text { e } 2000 \text { - Atlas de Desenvolvimento Humano no Recife, 2005; no ano 2007, consul- } \\
\text { ta a dados da Equipe Social da URB; no ano de } 2010 \text { (PCR, 2016a); e no ano de } 2012 \text { (PCR, } \\
\text { 2012). Notas: (1) A população da Comunidade do Pilar em } 2012 \text { foi feita através de estima- } \\
\text { tiva (ver Nota de Rodapé 183); e, (2) No ano de } 2010 \text { e 2012, a população aparece como } 60 \\
\text { anos ou mais. }\end{array}$} \\
\hline
\end{tabular}

De um modo geral, o Bairro do Recife tem uma população residente em grande maioria na Comunidade do Pilar e uma nova população de trabalhadores do Porto Digital. O Quadro 1 contrasta essas populações: trabalhadora do Porto Digital (Pesquisa de 2012), residente do Bairro do Recife (Censo 2010) e os chefes das famílias da Comunidade do Pilar (Diagnóstico de 2012). Em relação à escolaridade, observa-se a disparidade entre o alto nível de formação e até conhecimento em inglês da classe criativa, enquanto $18,3 \%$ dos residentes na Ilha são analfabetos e 53,50\% dos responsáveis por domicílio do Pilar têm apenas o fundamental incompleto. Sobre a renda, as cifras expostas ressaltam outra dessemelhança, assim como a forma de contratação, a qual 78,3\% da classe criativa contava com empregos pela Consolidação das Leis do Trabalho (CLT) contra somente 25,82\% de emprego formal dos chefes das famílias do Pilar. Ademais, a maioria dos trabalhadores do Porto Digital é do sexo masculino $(66,4 \%)$, enquanto na Comunidade a maioria dos chefes familiares é do sexo feminino (59,72\%). Em relação à idade, ambos são de maioria jovens. Contudo, enquanto é comum para um profissional da classe criativa concluir sua graduação até os 25 anos, os filhos e os netos das famílias do Pilar assumiram a responsabilidade de renda para sua sobrevivência (PCR, 2012). E apesar de não ter dados em relação à cor dos trabalhadores do Porto Digital, não foi observada uma predominância de negros e pardos tal como na Comunidade do Pilar. 
Quadro 1 - Porto Digital, B. do Recife e chefes dos núcleos familiares da C. do Pilar

\begin{tabular}{|c|c|c|c|}
\hline & $\begin{array}{l}\text { População trabalhadora do Porto } \\
\text { Digital }\end{array}$ & $\begin{array}{l}\text { População residen- } \\
\text { te do Bairro do Re- } \\
\text { cife }\end{array}$ & $\begin{array}{l}\text { Chefe dos núcleos familiares da Co- } \\
\text { munidade do Pilar }\end{array}$ \\
\hline Escolaridade & $\begin{array}{l}66,9 \% \text { com superior completo; } \\
85,3 \% \text { têm conhecimento em } \\
\text { inglês; } 29,6 \% \text { das empresas pos- } \\
\text { suem professores universitários } \\
\text { em seus quadros de funcionários }\end{array}$ & $\begin{array}{l}18,3 \% \text { de analfabe- } \\
\text { tismo da população } \\
\text { de } 10 \text { anos ou mais }\end{array}$ & $\begin{array}{l}6,54 \% \text { de analfabetos; } 53,50 \% \text { com } \\
\text { fundamental incompleto; } 10,05 \% \\
\text { com fundamental completo; } 8,41 \\
\text { com médio incompleto; } 15,89 \% \\
\text { com médio completo }\end{array}$ \\
\hline Renda & $\begin{array}{l}\text { Salário médio masculino de } \\
\mathrm{R} \$ 2.921,96 \text { e feminino de } \\
\mathrm{R} \$ 2.391,84 ; 78,3 \% \text { empregado } \\
\text { por CLT/pessoa física }\end{array}$ & $\begin{array}{l}\text { rendimento nomi- } \\
\text { nal médio mensal } \\
\text { por domicílio de } \\
\mathrm{R} \$ 567,00\end{array}$ & $\begin{array}{l}29,38 \% \text { de trabalho autônomo, } \\
\text { avulso ou biscate; } 25,82 \% \text { de em- } \\
\text { prego formal; } 15,17 \% \text { de bolsa fa- } \\
\text { mília; } 14,25 \% \text { de aposentadoria, } \\
\text { pensão e BPC/LOAS; e } 12,17 \% \text { sem } \\
\text { renda }\end{array}$ \\
\hline Sexo & $66,4 \%$ de homens & $\begin{array}{l}66,83 \% \text { de mulhe- } \\
\text { res responsáveis } \\
\text { por domicílio }\end{array}$ & $59,72 \%$ de mulheres \\
\hline Cor & - & $\begin{array}{l}65,11 \% \text { de negros e } \\
\text { pardos }\end{array}$ & - \\
\hline Idade & $55,1 \%$ entre 22 e 29 anos & $\begin{array}{l}45,85 \% \text { entre } 25 \text { e } \\
59 \text { anos }\end{array}$ & $76,45 \%$ até 25 anos \\
\hline
\end{tabular}

Fonte: População trabalhadora do Porto Digital (PD, 2012); População residente do Bairro do Recife (PCR, 2016a); e Chefe dos núcleos familiares da Comunidade do Pilar (PCR, 2012)

No caso da Favela, destaca-se ainda que $12,17 \%$ de seus chefes não tinham renda e os demais tinha fontes como trabalho autônomo, avulso ou biscate $(29,38 \%)$; Bolsa Família $(15,17 \%)$; e aposentadoria, pensão e Benefício da Prestação Continuada (BPC) da Lei Orgânica da Assistência Social (LOAS) (14,25\%). Suas principais atividades são não "criativas": 5,64\% dos chefes de família que trabalham de forma avulsa como estiva (função de trabalhador de porão) no Porto; 8,83\% de comerciantes; 7,12\% de serviços gerais; $5,41 \%$ de empregados domésticos; $29,13 \%$ afirmam não ter profissão; e "a ilegalidade advinda do tráfico de drogas e da prostituição, também faz parte da fonte de renda de alguns" (PCR, 2012, p. 16).

Assim, tais dados corroboram com os relatos e comprovam os processos de gentrificação com êxodo da população que residia em moradias formais no Bairro do Recife. Por se tratar de um processo lento, este ainda pode se consolidar com a viabilidade de moradia para classe média. Talvez seja por este "desejo" de tornar o bairro gentrificado que a população favelada, pobre e de maioria negra e parda não tenha ainda seus direitos à habitação, ao saneamento e à cidade respeitados; que seu plano de desenvolvimento aconteça de forma tão lenta; e que não sejam consideradas as crises sociais deste sistema, tais como o racismo estrutural e o papel da mulher no sustento de uma família periférica.

\section{Conclusão}

As transformações ocorridas no Bairro do Recife ao longo das últimas décadas são complexas devido aos diversos projetos e planos incidentes. Este trabalho permite analisar seus principais impactos no ambiente construído e em sua população. Trata-se de um processo de gentrificação com 
valorização imobiliária, êxodo de parte de sua população e criação de novos negócios turísticos, de entretenimento e empresarial. A entrada desses novos consumidores acontece através de turistas, da população de outros bairros, que utiliza o Bairro como espaço de entretenimento, e de empresas, sobretudo vinculadas ao Porto Digital.

Assim, por trás de um discurso de aumento de qualidade de vida, de retorno à centralidade, de devolução de uma área à cidade, de diversidade de usos e classes, de "Padrão FIFA" ou de economia de aglomeração, observa-se que o Bairro do Recife está sendo direcionado, através de diversos programas, planos e projetos urbanos, em grandes negócios para segmentos elitistas que promovem diversos processos de gentrificação e afastam cada vez mais a garantia de direitos humanos, principalmente das necessidades habitacionais e de outras funções sociais da cidade. Nessa "reconquista" de territórios deprimidos de investimentos, em vez de diminuir, são acirradas as barreiras, seus contrastes e as desigualdades da capital mais desigual do Brasil.

\section{Referências}

AD/DIPER (Agência de Desenvolvimento Econômico do Estado de Pernambuco). Plano de Revitalização Bairro do Recife: Volume I - Planejamento Urbano e Economia. Recife, 1992.

ALBUQUERQUE, I. J. C.; LACERDA, N. Normas indutoras e interesse público: o Porto Digital (Bairro do Recife) e captura da coisa pública. In: Encontro Nacional da Anpur, 27. 2017, São Paulo. Anais [...]. São Paulo: ANPUR, 2017.

ADHR. ATLAS DE DESENVOLVIMENTO HUMANO NO RECIFE. Software 2005. Versão 1.0.2. Disponível em: https://www.recife.pe.gov.br/pr/secplanejamento/pnud2006/. Acesso em: 11 nov. 2017.

BRANDÃO, Z.; NASCIMENTO, C. F. B.; CARVALHO, L. M. Porto. In: BRANDÃO, Z. (Org.). Núcleo Técnico de Operações Urbanas: estudos 2007 - 2010. Recife: CEPE, 2012. p. 105-139.

DEUTSCHE, R.; RYAN, C. G. El bello arte de la gentrificación. In: OBSERVATORIO METROPOLITANO DE MADRID (Org.). El Mercado contra la ciudad: Sobre globalización, gentrificación y políticas urbanas. Madrid: Ed. Traficantes de Sueños, 2015. p. 27-52.

DU (Direitos Urbanos). Liberdade para o Recife Antigo! Corra que a polícia vem ai! Disponível em: https://direitosurbanos.wordpress.com/2015/01/16/liberdade-para-o-recife-antigo-corra-que-a-policia-vem-ai/. Acesso em: 22 dez. 2017a.

DU (Direitos Urbanos). Comunidade Pilar: quando o esquecimento fere. Disponível em: https://direitosurbanos.wordpress.com/2015/06/25/comunidade-pilar-quando-o-esquecimento-fere/. Acesso em: 22 dez. 2017b.

JACQUES, P. B. Errâncias urbanas: a arte de andar pela cidade. Caminhos alternativos à espetacularização das cidades. ARQTEXTO, Porto Alegre, v. 7, p. 16-25, 2005.

LACERDA, N.; FERNANDES, A. C. Parques tecnológicos: entre a inovação e renda imobiliária no contexto da 
metrópole recifense (Brasil). Cadernos Metrópole, São Paulo, v. 17, p. 329-354, 2015.

LEITE, R. P. Patrimônio e enobrecimento no Bairro do Recife. Revista CPC, São Paulo, v. 2, p. 14-26, 2006.

LIMA JUNIOR, P. N. Uma estratégia chamada "planejamento estratégico": deslocamentos espaciais e a atribuição de sentidos na terapia do planejamento urbano. Rio de Janeiro: 7Letras, 2010.

MENDES, Luís. Gentrificação turística em Lisboa: neoliberalismo, financeirização e urbanismo austeritário em tempos de pós-crise capitalista 2008-2009. Cadernos Metrópole, São Paulo, v. 19, n. 39, p. 479-512, maio/ago. 2017.

MONTEnegro, A. T.; SALES, I. C.; COIMBRA, S. R. Memória em Movimento: Bairro do Recife, Porto de Muitas histórias. Recife: Gráfica Recife, 1989.

MELO, J. M. Mais além da rua do Bom Jesus: a revitalização do bairro do Recife, a população e outros usos do local. Dissertação (Mestrado em Antropologia) - Universidade Federal de Pernambuco, Recife, 2003.

NERY, N. S. Inclusão socioespacial de comunidades pobres: programa de requalificação urbanística e inclusão social da Comunidade do Pilar, Bairro do Recife- PE. Dissertação (Mestrado em Geografia) - Universidade Federal de Pernambuco, Recife, 2012.

NERY, N. S.; CASTILHO, C. J. M. A comunidade do Pilar e a revitalização do bairro do Recife: possibilidades de inclusão socioespacial dos moradores ou gentrificação. Humanae, Recife, v. 1, n. 2, p. 19-36, 2008.

OMM. OBSERVATORIO METROPOLITANO DE MADRID. EI Mercado contra la ciudad: Sobre globalización, gentrificación y políticas urbanas. Madrid: Ed. Traficantes de Sueños, 2015.

PCR (PREFEITURA DA CIDADE DO RECIFE). Relatório de Atividades - Memória em Movimento. Recife: Serviço de Pesquisa e Documentação no Bairro do Recife, 1989.

PCR (PREFEITURA DA CIDADE DO RECIFE). Plano de Desenvolvimento do Porto Digital. Recife: Gerência de Planejamento Urbano, 2001a.

PCR (PREFEITURA DA CIDADE DO RECIFE). Processo de Revitalização do Bairro do Recife 1986/2001. Recife: URB-Recife, 2001b.

PCR (PREFEITURA DA CIDADE DO RECIFE). Bairro do Recife, Planejamento Interpretativo: Relatório da Equipe de Apoio Social. Recife: Empresa de Urbanização do Recife, 2002.

PD (PORTO DIGITAL). \$ustentabilidade dos Parques Tecnológicos: Sustentabilidade financeira e competitividade do território. Workshop Anprotec, 19., 2011, Porto Alegre. Anais [...]. Porto Alegre: Anprotec, 2011.

PD (PORTO DIGITAL). 0 que é o Porto Digital. Disponível em: http://www.portodigital.org/parque/o-que-e-o-porto-digital. Acesso em: 25 nov. 2017.

RECIFE. Lei no 13.957 de 26 de setembro de 1979. Recife, PE, 1979. 
RECIFE. Lei no 16.290 de 29 de janeiro de 1997. Recife, PE, 1997.

RECIFE. Lei n 13.156, de 4 de dezembro de 2006. Recife, PE, 2006a.

RECIFE. Lei no 17.244, de 27 de julho de 2006. Recife, PE, 2006b.

RECIFE. Lei no 18.337 de 05 de julho de 2017. Recife, PE, 2017.

SANTANA, J. V. Gestão de cidades, infraestrutura e discurso de diminuição da pobreza do BID: notas sobre Brasil e Argentina. In: GOMES, M. F. C. M. (Ed.). Renovação urbana, mercantilização da cidade e desigualdades sociais. Rio de Janeiro: Mauad X, 2013. p. 80-95.

SEQUERA, J. A 50 años del nacimiento del concepto 'gentrificación'. La mirada anglosajona. Revista Bibliográfica de Geografía y Ciencias Sociales. Barcelona, v.. XX, n. 1.127, p. 1-23. 25, 2015.

SIMAS, Tarciso Binoti. A competição das cidades pela inovação e os processos de gentrificação nos casos Porto Digital em Recife e 22@Barcelona. Tese (Doutorado em Urbanismo) - Universidade Federal do Rio de Janeiro, Rio de Janeiro, 2018.

SMITH, N. La nueva frontera urbana: Ciudad revanchista y gentrificación. Madrid: Ed. Traficantes de Sueños, 2012.

SMITH, N. Nuevo Globalismo y nuevo urbanismo. La gentrificación como estrategia urbana local. In: OBSERVATORIO METROPOLITANO DE MADRID (Org.). El Mercado contra la ciudad: Sobre globalización, gentrificación y políticas urbanas. Madrid: Ed. Traficantes de Sueños, 2015. p. 245-273.

SOUZA, L. H.; LAPA, T. A. O processo de revitalização e atividade turística no 'Bairro do Recife' (Recife, Pernambuco, Brasil): interposições ao desenvolvimento humano no contexto das teorias das cidades sustentáveis e da conservação integrada. Turismo e Sociedade, v. 8, n, 1, p. 124-144, 2015.

VAINER, C. Pátria, empresa e mercadoria. In: ARANTES, O.; VAINER, C.; MARICATO, E. (Org.). A cidade do pensamento único: desmanchando consensos. Petrópolis: Vozes, 2013. p. 75-104.

VIEIRA, N. M. Gestão de sítios históricos: a transformação dos valores culturais e econômicos nas fases de formulação e implementação de programas de revitalização em áreas históricas. Tese (Doutorado em Desenvolvimento Urbano) - Universidade Federal de Pernambuco, Recife, 2006.

ZANCHETI, S. M.; LACERDA, N. O desempenho do Plano de revitalização do Bairro do Recife: o caso do Polo Bom Jesus. In: ZANCHETI, S.; LACERDA, N.; MARINHO, G. (Org.). Revitalização do Bairro do Recife: Plano, Regularização e Avaliação. Recife: Editora Universitária da UFPE, 1998. 89-135.

ZANCHETI, S.; MARINHO, G.; LACERDA, N. Revitalização do Bairro do Recife: Plano, Regulação e Avaliação. Recife: Editora Universitária da UFPE, 1998. 